\title{
DO YOUNG POLISH CHILDREN STRUGGLE WITH OVERWEIGHT AND OBESITY?
}

\section{CZY POLSKIE DZIECI ZMAGAJĄ SIĘ Z NADWAGĄ I OTYŁOŚCIĄ?}

\author{
Magdalena Potempa-Jeziorowska ${ }^{1(\mathrm{~A}, \mathrm{~B}, \mathrm{D}, \mathrm{E}, \mathrm{F})}$, Paweł Jonczyk ${ }^{1(\mathrm{~A}, \mathrm{~B}, \mathrm{E}, \mathrm{F})}$, \\ Elżbieta Świętochowska ${ }^{2(A, C, D)}$, Marek Kucharzewski ${ }^{1(A, D, F)}$
}

\author{
${ }^{1}$ Department of Descriptive and Topographic Anatomy, Faculty of Medical Sciences in Zabrze, \\ Medical University of Silesia, Katowice, Poland \\ ${ }^{2}$ Department of Medical and Molecular Biology, Faculty of Medical Sciences in Zabrze, \\ Medical University of Silesia, Katowice, Poland
}

Authors' contribution

Wkład autorów:

A. Study design/planning

zaplanowanie badań

B. Data collection/entry

zebranie danych

C. Data analysis/statistics

dane - analiza i statystyki

D. Data interpretation

interpretacja danych

E. Preparation of manuscript

przygotowanie artykułu

F. Literature analysis/search

wyszukiwanie i analiza literatury

G. Funds collection

zebranie funduszy

\section{Summary}

Background. Excess body mass is an alarming issue among children today. The goal of the study was to evaluate the nutritional status of young primary-aged school children in Poland.

Material and methods. The study included children $(n=908)$ between 6 and 10 years of age attending elementary schools in urban and rural areas of Poland. An original questionnaire was used as the research tool in the study, which parents of the children completed. The questionnaire contained 40 questions divided into 4 parts (basic anthropometric data and family information, dietary habits, level of physical activity and level of parents' knowledge about principles of nutrition). Nutritional status was defined by BMI values based on standardized BMI charts recommended by WHO.

Results. The study found that $74.7 \%$ of children had a normal or ideal body mass and $17.1 \%$ had excess body weight (overweight and obesity). Obesity was found in $6.8 \%$ of children and overweight in $10.3 \%$. The study didn't reveal any significant differences in the prevalence of obesity among boys versus girls; however, overweight was found to be significantly higher among boys compared with girls $(p<0.05)$. Children's nutritional status was similar regardless of where they lived.

Conclusions. Prevalence of eating disorders among children is at a significant level. Obesity was found to be the most uncommon eating disorder in this study group, as opposed to overweight, which was the most common. However, because the study was based on a self-reporting questionnaire, there may be issues of accuracy, reliability and compliance, especially in case of weight disorders.

Keywords: overweight, eating disorders, obesity, children

\section{Streszczenie}

Wprowadzenie. Występowanie nadmiernej masy ciała jest obecnie niepokojącym problemem wśród dzieci. Celem pracy jest ocena stanu odżywienia wśród polskich dzieci uczęszczających do szkół podstawowych.

Materiał i metody. Uczestnikami badania były dzieci w wieku 6-10 lat (n=908), uczęszczające do szkół podstawowych w Polsce, zamieszkujące zarówno miejskie jak i wiejskie tereny. Narzędziem badawczym był autorski kwestionariusz ankiety, który wypełniany był przez rodziców uczniów. Ankieta zawierała 40 pytań i była podzielona na 4 części (podstawowe dane antropometryczne dziecka i informacje o rodzinie, zwyczaje żywieniowe, poziom aktywności fizycznej oraz wiedza rodziców na temat prawidłowych zasad odżywiania się). Stan odżywienia określany był za pomocą wskaźnika BMI u dzieci z zastosowaniem odpowiednich dla płci i wieku siatek centylowych opracowanych przez WHO. Wyniki. Prawidłowa masa ciała charakteryzowała $74,7 \%$ badanych dzieci. Nadmiar masy ciała (nadwaga i otyłość) występował u $17,1 \%$, z czego otyłych było $6,8 \%$ dzieci, nadwagę posiadało $10,3 \%$ badanych. W badaniu nie wykazano różnic międzypłciowych w zakresie częstości występowania otyłości, jednak w zakresie częstości występowania nadwagi wykazano statystycznie istotną przewaga występowania wśród chłopców $(p<0,05)$. Stan odżywienia dzieci był podobny niezależnie od miejsca zamieszkania.

Wnioski. Czesstość występowania zaburzeń odżywiania wśród dzieci jest na znaczącym poziomie. Jednocześnie otyłość była najrzadziej stwierdzanym zaburzeniem masy ciała u dzieci, w przeciwieństwie do nadwagi, która rozpoznawano w badanej grupie najczęściej. Ze względu na charakter badania polegający na samoocenie autorzy wskazują, iż otrzymane dane mogą się nieco różnić, szczególnie w zakresie zaburzeń masy ciała.

Słowa kluczowe: nadwaga, zaburzenia odżywienia, otyłość, dzieci
Tables: 6

Figures: 3

References: 28

Submitted: 2021 Jul 12

Accepted: 2021 Oct 13

Potempa-Jeziorowska M, Jonczyk P, Świętochowska E, Kucharzewski M. Do young Polish children struggle with overweight and obesity?. Health Prob Civil. 2022; 16(1): 37-47. https://doi.org/10.5114/hpc.2021.110039

Address for correspondence / Adres korespondencyjny: Magdalena Potempa-Jeziorowska, Department of Descriptive and Topographic Anatomy, Faculty of Medical Sciences in Zabrze, Medical University of Silesia, Katowice, Plac Traugutta 2, 41-800 Zabrze, Poland, e-mail: magdalenapotempa@o2.pl, phone: +48 32 271 72 10 ORCID: Magdalena Potempa-Jeziorowska https://orcid.org/0000-0002-7655-0151, Paweł Jonczyk https://orcid.org/0000-0001-6968-7371, Elżbieta Świętochowska https://orcid.org/0000-0001-5787-7880, Marek Kucharzewski https://orcid.org/0000-0001-7950-679X

Copyright: (C) John Paul II University of Applied Sciences in Biala Podlaska, Magdalena Potempa-Jeziorowska, Paweł Jonczyk, Elżbieta Świętochowska, Marek Kucharzewski. This is an Open Access journal, all articles are distributed under the terms of the Creative Commons Attribution-NonCommercial-ShareAlike 4.0 International (CC BY-NC-SA 4.0) License (http://creativecommons.org/licenses/by-nc-sa/4.0/), allowing third parties to copy and redistribute the material in any medium or format and to remix, transform, and build upon the material, provided the original work is properly cited and states its license. 


\section{Introduction}

Eating disorders are one of the most serious public health challenges of the 21st century. Since 1975, the prevalence of obesity has nearly tripled worldwide. The increasing rise in overweight and obesity among children is a particularly alarming trend in developed countries. Obesity has serious medical, social and economic consequences. Hence, it is also called " $21^{\text {st }}$ century epidemic" or a disease of civilization [1]. The vast majority of obesity and overweight cases involve obesity, which can be attributed to environmental factors such as improper dietary habits and sedentary lifestyles, resulting in an excess of energy consumption. Nowadays, despite the increasing popularity of healthy lifestyles, there is still a strong trend towards unhealthy behaviors among children $[2,3]$. Health problems that begin in childhood intensify with age. Obese children are likely to be obese in adulthood and develop serious health problems early. A permanent positive energy balance promotes the accumulation of visceral fat. It alters many metabolic pathways and leads to the predominance of anabolic ones which disturb homeostasis and lead to metabolic disorders. Many chronic clinical conditions characteristic in adults now begin more commonly in children. These include central adiposity, hypertension, dyslipidemia, prediabetes and type 2 diabetes, and a combination of these lead to metabolic syndrome (MetS). Obesity is an essential component of MetS [4]. Over the last several years, MetS has been increasing among children. Its occurrence is difficult to estimate because of MetS diagnostic criteria that is not clearly defined. According to a review by Friend et al., the median prevalence of MetS in the entire population of children was 3.3\%; however, in overweight children, MetS was present in approximately $12 \%$. Moreover, among obese children, approximately $1 / 3$ of them were MetS burdened [5]. Usually, the reduction of fat mass leads to improved values of all components of MetS. But in practice, obesity is difficult to treat at all ages. It is a chronic condition that requires multidisciplinary treatment interventions.

The evaluation of nutritional status is complex as it includes several factors, which can be divided into external factors such as food safety and cultural and socioeconomic effects, and internal ones like age, sex, nutritional habits, physical activity and comorbidities. The mnemonic "ABCDE" can be helpful to holistically assess the nutritional status of an individual. The letters stand for:

A - Anthropometric method,

B - Biochemical method,

C - Clinical method,

D - Demographic method,

E - Environmental and Social factors method [6].

In clinical practice, as well as in population studies, the " $\mathrm{A}$ " method is most popular in more easily and readily evaluating nutritional status. Human body measurements (weight and height) are commonly used to calculate body mass index (BMI). According to recommendations from the World Health Organization (WHO), overweight in adults is diagnosed when BMI is between 25 and $29.9 \mathrm{~kg} / \mathrm{m}^{2}$. Obesity is defined as follows:

- Class I obesity = BMI between 30 and $34.9 \mathrm{~kg} / \mathrm{m}^{2}$,

- Class II obesity = BMI between 35 and $39.9 \mathrm{~kg} / \mathrm{m}^{2 \prime}$

- Class III obesity = BMI over $40 \mathrm{~kg} / \mathrm{m}^{2}$, also known as severe obesity [7].

Among children, the BMI index is also used but its value is set based on standardized BMI growth charts based on age and sex. There are fewer definitions of overweight and obesity in children and adolescents. The most popular are those developed by WHO in 2007 for children 5-19 years old. According to its definition, BMI values at or above 2 standard deviations of the WHO growth standard median (corresponds to the $95^{\text {th }}$ percentile) in growth charts are categorized as obese. Overweight is defined as a BMI $>1$ standard deviation above the WHO growth standard median (corresponds to BMIs between $85^{\text {th }}-95^{\text {th }}$ percentile) for children and teens of the same age and sex. The range between the $5^{\text {th }}$ to $85^{\text {th }}$ percentile defines normal weight. Children having a BMI under 2 standard deviations (under $5^{\text {th }}$ percentile) are underweight [8]. The other definitions for nutritional state assessment in children are created by the US Centers for Disease Control and Prevention (CDC) and International Obesity Task Force (IOTF) [9,10]. Their criteria are shown in Figure 1. 


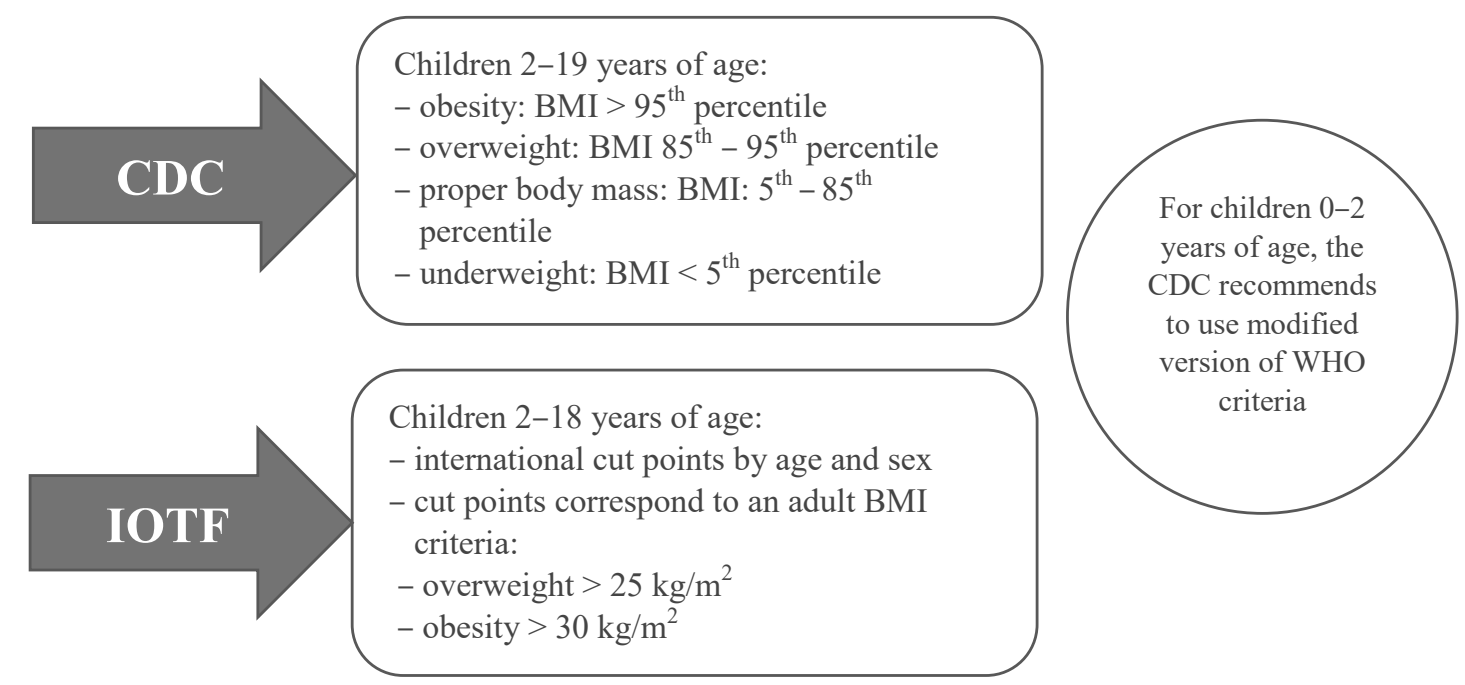

Figure 1. Obesity and overweight criteria defined by the US Centers for Disease Control and Prevention (CDC) and International Obesity Task Force (IOTF) $[9,10]$

In Poland, referential BMI growth charts are based on a large nationwide OLAF study conducted in 20072009 among children 7-12 years of age. They are recommended for use in clinical practice to assess nutritional status [11].

The main goal of the study was to evaluate the prevalence of body mass disorders among children 6-10 years of age attending select primary schools in Poland.

\section{Material and methods}

This study included 908 children, 6 to 10 years of age, attending elementary schools in select urban and rural areas in Poland. The study took place after obtaining consent to participate by the headmasters of the schools. The researchers planned to distribute questionnaires to 5 schools in every Polish region; however, they didn't get consent from all the headmasters of the schools. Finally, questionnaires were given to 2 primary schools in every Polish region except Silesian where questionnaires were distributed to 8 schools. A total of 38 schools took part in the study. The lowest number of students attending the schools was 150 . The study tool was a questionnaire completed by one of the parents of the children. The questionnaire's main content was based on reference information about principles of nutrition published in the Nutrition Standards for Polish Population (edition: 2017) developed by the Food and Nutrition Institute [12].

The survey was originally created by the authors of this study. It mainly contained 40 one-choice questions and was thematically divided into 4 groups. The researchers' intention was to formulate the questionnaire in accordance to the ABCDE method and to include more holistic information in assessing nutritional status. The first part of the questionnaire included basic self-reported anthropometric data (weight, height) and sociodemographic information about the family. The second part was the main part, which was geared towards obtaining information about dietary habits. The third section focused on level of physical activity among children and their parents, while the last part of the study was dedicated to the parents of children and contained questions about principles and rules of proper nutrition. The questionnaires were completed by parents during school meetings or at home with instruction from the researchers. Participation in the study was voluntary and anonymous. Between September 2018 and March 2019, the researchers distributed 5,000 questionnaires and the response rate was $20.2 \%$ (getting back 1,010 questionnaires). The analysis only included questionnaires that had the first part completed and as such, this paper contains data from the first part of the survey.

BMI values were calculated based on self-reported weight and height of the children. To define nutritional status, standardized BMI sex and age growth charts based on WHO recommendations for children 5-19 years of age were used [8]. 
Ethics

The Ethics Committee of the Medical University of Silesia in Katowice issued approval (No. KNW/0022/ KB1/94/I/18/19) to conduct the research. The study was conducted according to the principles in the Declaration of Helsinki. Participation in the study was voluntary and anonymous. The participants and their legal guardians provided assent and written informed consent to participate in this study.

\section{Statistics}

Data were analyzed using IBM SPSS Statistics version 25. Comparative analyses were performed using the parametric Student t-test for independent samples as well as the nonparametric Mann-Whitney $U$ and Kruskal-Wallis tests. Correlation analysis was performed using the Pearson correlation $(r)$ and Spearman's correlation $(r h o)$. A value of $p \leq 0.05$ was taken to be statistically significant.

\section{Results}

\section{Research group}

The research group included 908 children with approximately an equal number of boys and girls (470 girls; $51.76 \%$ and 438 boys; $48.24 \%$ ). The largest group of children was 8 years old among both boys and girls. Detailed age characteristics of the group is presented in Table 1 . The places where children taking part in the study lived include rural areas, town (up to 100,000 residents) or city (over 100,000 in population) (Figure 2).

Table 1. Age of the participants

\begin{tabular}{|c|c|c|}
\hline Age (years) & Number of Girls & Number of Boys \\
\hline 6 & 9 & 4 \\
\hline 7 & 104 & 85 \\
\hline 8 & 130 & 120 \\
\hline 9 & 128 & 119 \\
\hline 10 & 99 & 110 \\
\hline Total & $\mathbf{4 7 0}$ & $\mathbf{4 3 8}$ \\
\hline
\end{tabular}

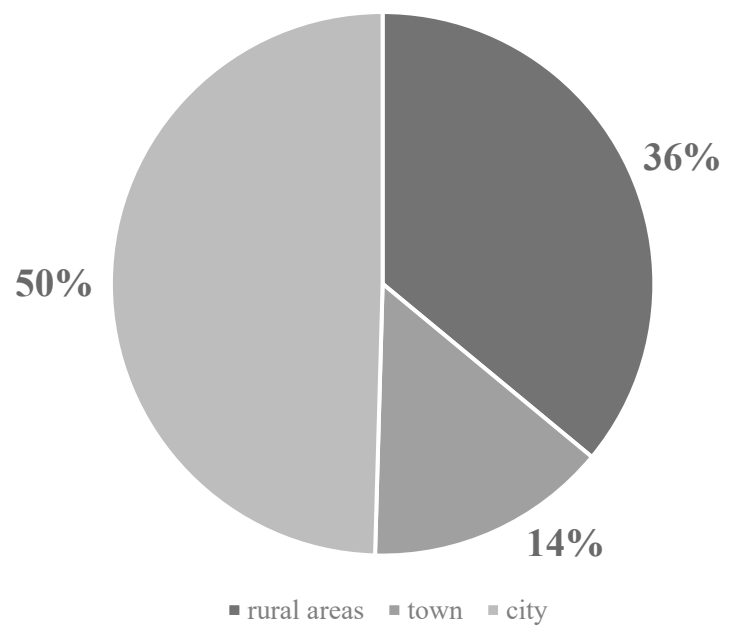

Figure 2. Place of residence of the participants 


\section{Nutritional status}

Results show that three quarters of the children (74.7\%) had ideal body mass. Nearly one fifth of the children (17.1\%) was recognized to have excess body weight (overweight and obesity), with obesity present among $6.8 \%$ of all children and overweight among 10.3\%. Among all participants, 8.2\% were underweight (Figure 3).

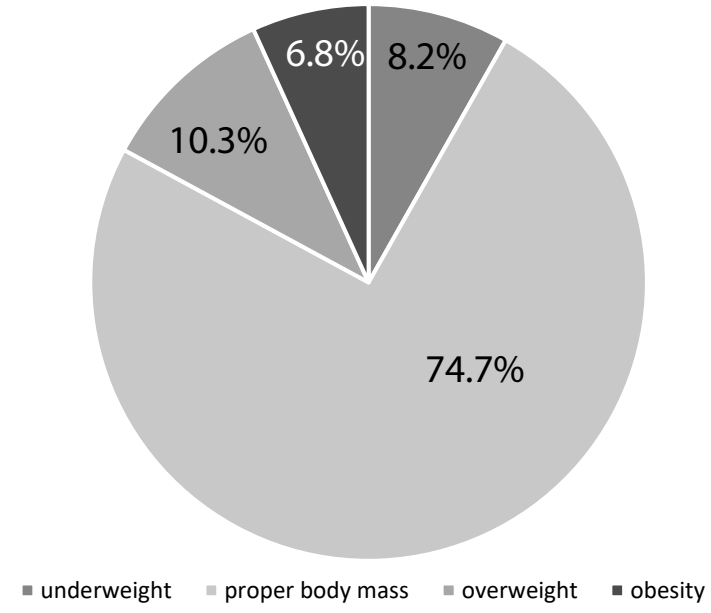

Figure 3. Nutritional status of the participants

Among girls, three quarters were characterized to have normal body mass (76.1\%); however, overweight and obesity was found in $7.5 \%$ and $7.0 \%$, respectively of the girls. A relative high rate (9.4\%) of underweight was found among the girls in the study. In the boys group, overweight and obesity was found to be $13.3 \%$ and $6.6 \%$, respectively (Table 2). Obesity wasn't more characteristic to any one of the boys or girls groups. However, overweight was found to be significantly higher among boys compared with girls $(p<0.05)$.

Table 2. Age and sex specific nutritional status of the participants

\begin{tabular}{|c|c|c|c|c|c|c|c|c|}
\hline & \multicolumn{2}{|c|}{ Underweight } & \multicolumn{2}{c|}{ Normal Body Mass } & \multicolumn{2}{c|}{ Overweight } & \multicolumn{2}{c|}{ Obesity } \\
\cline { 2 - 9 } & $\mathbf{n}$ & $\mathbf{\%}$ & $\mathbf{n}$ & $\mathbf{\%}$ & $\mathbf{n}$ & $\mathbf{\%}$ & $\mathbf{n}$ & $\mathbf{\%}$ \\
\hline Girls & 44 & 9.4 & 357 & 76.1 & 35 & 7.5 & 33 & 7.0 \\
\hline Boys & 30 & 6.9 & 320 & 73.2 & 58 & 13.3 & 29 & 6.6 \\
\hline
\end{tabular}

The problem of obesity was greatest among 9-year-old girls (9.4\%) and among 7-year-old boys (8.3\%). The smallest percentage of obesity was found in 8-year-old girls and none of the 6-year-old children were obese. In any group, the percentage of obesity was not above $10 \%$.

Beyond 6 years of age, for every age group, overweight was more prevalent among boys than girls. The highest prevalence of overweight was found in boys 8 years of age - nearly 15\% (14.2\%) were overweight. This means that one in seven boys is overweight in this group. Moreover, among the group of boys between the ages of 7 and 8, one fifth of each age group struggled with overweight and obesity (21.4\% and 21.7\%, respectively). Among girls, overweight was most characteristic for 6- (25\%) and 7-year-old girls (9.6\%).

The largest number of children with normal body mass was found among girls 8 years of age. Study data indicated that $87.1 \%$ of 8 -year-old girls had normal body mass. Among boys, all 6-year-old had normal body mass. In contrast, less than $70 \%(67.9 \%)$ of boys and $72.1 \%$ of girls 7 years of age had ideal body mass.

Underweight was mostly recognized among 7 - and 10 -year-old girls ( $9.6 \%$ and $10.1 \%$, respectively). Among boys, malnutrition was most characteristic in the 7-years-old group with the $10.7 \%$ of being underweight. Only $2.3 \%$ of 9 -year-old girls were found to be underweight and none of the 6 -year-old boys were malnourished. The data on the nutritional status of girls and boys are presented in Tables 3 and 4, respectively. 
Table 3. Age distribution of the nutritional status of the girls in the study

\begin{tabular}{|c|c|c|c|c|}
\hline Age & Underweight (\%) & Normal Body Mass (\%) & Overweight (\%) & Obesity (\%) \\
\hline \multicolumn{5}{|c|}{ Girls } \\
\hline 6 & 0 & 75 & 25 & 0 \\
\hline 7 & 9.6 & 72.1 & 9.6 & 8.7 \\
\hline 8 & 4.6 & 87.1 & 3.8 & 4.6 \\
\hline 9 & 2.3 & 80.4 & 7.8 & 9.4 \\
\hline 10 & 10.1 & 75.8 & 8.1 & 6.1 \\
\hline
\end{tabular}

Table 4. Age distribution of the nutritional status of boys in the study

\begin{tabular}{|c|c|c|c|c|}
\hline Age & Underweight (\%) & Normal Body Mass (\%) & Overweight (\%) & Obesity (\%) \\
\hline & \multicolumn{5}{|c|}{ Boys } \\
\hline 6 & 0 & 100 & 0 & 0 \\
\hline 7 & 10.7 & 67.9 & 13.1 & 7.3 \\
\hline 8 & 5.8 & 72.5 & 14.2 & 5.5 \\
\hline 9 & 5.9 & 76.5 & 11.8 & 7.5 \\
\hline 10 & 6.4 & 74.5 & 11.8 & \\
\hline
\end{tabular}

Study data indicate the median standard BMI for girls $\left(16.41 \mathrm{~kg} / \mathrm{m}^{2}\right)$ is statistically significantly lower than boys' median BMI values $\left(17.2 \mathrm{~kg} / \mathrm{m}^{2} ; p=0.001\right)$ (Table 5$)$.

Table 5. Mean values, standard deviations and statistical significance of BMI based on sex

\begin{tabular}{|c|c|c|c|c|c|c|c|c|c|}
\hline & \multicolumn{2}{|c|}{ Girls } & \multicolumn{2}{c|}{ Boys } & \multirow{2}{*}{$\boldsymbol{t}$} & \multicolumn{3}{c|}{$\boldsymbol{p}$} & \multicolumn{3}{c|}{ C5\% } \\
\cline { 2 - 8 } & $\boldsymbol{M}$ & $\boldsymbol{S D}$ & $\boldsymbol{M}$ & $\boldsymbol{S D}$ & & & $\boldsymbol{L}$ & $\boldsymbol{U}$ & Cohen's d \\
\hline BMI & 16.41 & 2.93 & 17.2 & 3.34 & -3.75 & 0.001 & -1.19 & -0.37 & 0.25 \\
\hline
\end{tabular}

According to the results, children had similar nutritional status regardless of where they lived (city, town, rural). A correlation between body mass and place of residence was not found ( $p=0.334$ ) (Table 6).

Table 6. Median values, standard deviations and statistical significance of BMI based on place of residence

\begin{tabular}{|c|c|c|c|c|c|c|c|c|c|}
\hline & \multicolumn{2}{|c|}{ Rural Areas } & \multicolumn{2}{c|}{ Town } & \multicolumn{2}{c|}{ City } & \multirow{2}{*}{$\boldsymbol{H}$} & \multirow{2}{*}{$\boldsymbol{\boldsymbol { E } ^ { 2 }}$} \\
\cline { 2 - 10 } & $\boldsymbol{M}$ & $\boldsymbol{S D}$ & $\boldsymbol{M}$ & $\boldsymbol{S D}$ & $\boldsymbol{M}$ & $\boldsymbol{S D}$ & & 0.334 & 0.01 \\
\hline BMI & 16.67 & 2.76 & 17.11 & 3.07 & 16.78 & 3.44 & 2.19 & 0.19 \\
\hline
\end{tabular}

\section{Discussion}

One of the most important aspects of pediatric medical care is monitoring and assessing growth. This study examined a vital issue concerning the nutritional status of children. Primary school-aged children are at a stage of intensive physical and mental growth, necessitating a well-balanced diet. Eating disorders like overweight and obesity are typically a result of an unhealthy lifestyle. Different behavioral factors like sedentary lifestyle and bad dietary habits promote weight gain at every age. This is particularly important for children as there is evidence that children learn the most about forming proper dietary habits and a healthy lifestyle up until the age of 10. The psychological aspect of eating disorders should also not be ignored. While there are not a lot of studies on the psychology of eating, there is evidence that children with obesity are more likely to experience rejection and teasing from their peers. As such, overweight and obesity in children are also linked with a higher risk of psychosocial and emotional problems $[13,14]$.

This study provides a source of reliable data about the nutritional status of nearly 1,000 Polish primary school students 6-10 years of age. The WHO emphasizes the impact of eating disorders and the importance of healthy behaviors. It leads many efforts through its Health in All Policies (HiAP) approach to improve the population's diet. It also regularly monitors healthy behaviors among children. For example, the European Childhood Obesity Surveillance Initiative (COSI) Study was conducted on behalf of the WHO. The COSI study 
involves the assessment of nutritional status, dietary habits and physical activity trends in 300,000 children across the WHO European Region. It has measured trends in overweight and obesity among primary school children 7-9 years of age and over 10 years. According to the fourth round report of the study for 2015-2016, the prevalence of overweight and obesity in Europe was $29 \%$ for boys and $27 \%$ for girls (the average value across the countries). Obesity was reported in 13\% of European boys and $9 \%$ of girls. The fourth round of COSI also marked the first time that Poland participated in the study. The sample group included about 5,000 children 8 years of age who attended randomly selected primary schools. The data showed the prevalence of overweight and obesity in children slightly exceeding the middle range. In Poland, the problem of obesity affects $14 \%$ boys and $10 \%$ girls. The percentage of overweight children (including obesity) reaches 32\% among boys and $29 \%$ among girls. Although our study involved a smaller sample group than the COSI study, our data indicate a lower prevalence of obesity in the studied population. The age distribution of obesity in the COSI study is in line with our results. In both studies, boys struggled with overweight and obesity more often. Compared with other countries, the highest prevalence of obesity was noticed in the Mediterranean countries (Cyprus, Spain, Greece, Malta, and Italy), and the lowest values in central Asian countries (Tajikistan, Kyrgyzstan) and Scandinavian European countries [15]. In a 2017-2018 study by Fryar et al. conducted in the United States among children and adolescents between the ages of 2 and 19 years, the prevalence of obesity was $19.3 \%$, affecting about 14.4 million children and adolescents, with $6.1 \%$ suffering from severe obesity and another $16.1 \%$ being overweight. About one in five children 6 to 11 years was obese [16].

In Poland, studies on the prevalence of overweight and obesity among children and adolescents have been conducted for years but few have examined the issue at a nationwide level, particularly among early primary school-aged children. In 2005, Malecka-Tendera et al. conducted a study according to the protocol of the European Childhood Obesity Group. It estimate the prevalence of overweight and obesity among children 7-9 years of age attending primary schools in Poland. The sample group included 2,916 children. The results showed that overweight (and obesity) was found in $15.4 \%$ of children (15.8\% girls and $15.0 \%$ boys). Obesity was present among only $3.6 \%$ of the children studied. The study also revealed a decreasing trend of obesity and overweight prevalence throughout age classes. These results are rather different from those obtained in our study, with the percentage of obese children (both boys and girls) in our study being higher. Nonetheless, while the prevalence of overweight is similar, the long period of time between the cited study and our own (2005 vs. 2021) should be taken into consideration. Moreover, the study by Małecka-Tendera and our study used different standards for obesity and overweight estimation (International Obesity Task Force vs. WHO recommendations, respectively), which may impact the results [17]. In 2010, another interesting study was published that assessed the occurrence of overweight and obesity among nearly 8,000 Polish adolescents 13-15 years of age. The study results were based on IOTF and national reference standards (the cut-off value for obesity was the $97^{\text {th }}$ percentile and for overweight, the $90^{\text {th }}$ percentile). The data were compared to data collected in 1995. According to the results, overweight and obesity occurred at a level of $12.5 \%$ and $1.9 \%$, respectively. A statistically significant correlation was not found between the percentage of overweight and obese children and children's place of residence. The study also revealed a $2 \%$ increase in the prevalence of overweight and obesity in 2005 compared to 1995 [18]. However, a study by Brzezinski et al. did not confirm this trend. According to the study, there was no upward trend in the prevalence of overweight and obesity among children in an 18-year-long observation period. However, an age-related increase in the prevalence of excess body mass was observed in all age categories of boys and prepubescent girls $(p<0.05)[19]$.

In 2016, Kułaga et al. published an extensive, randomized Polish study on the assessment of the nutritional status of children 7-18 years of age. The study included about 17,000 children attending school in all regions of Poland. Three standardized childhood obesity definitions (CDC, IOTF, and WHO recommendations) were used in the study. The results showed that excess weight among children 7-12 years of age was in the range of 21.7$30.4 \%$ for boys and $18.4-23.2 \%$ for girls, depending on the obesity standards used. The prevalence of obesity among this age group of children was in the range of $5.5-13.1 \%$ for boys and $3.6-6.4 \%$ for girls. However, the prevalence of overweight and obesity among adolescents was lower than in the younger group, ranging from 14.6 to $19.4 \%$ for boys and from 10.3 to $13.0 \%$ for girls. This was similar in the case of obesity. The prevalence of obesity among adolescents was in the range of 3.4-5.0\% and 2.0-2.6\% for boys and girls, respectively [20]. Overall, there was a higher prevalence of obesity and overweight than in our study. Our sample group included children up to 10 years of age, whereas Kułaga's study group included slightly older children between 7 and 12 years of age. Additionally, our study did not show any sex-based difference in obesity prevalence in contrast to the Kulaga study.

One of the newest nationwide Polish studies, 'Health and Lifestyle among Polish Pupils', was conducted under the National Health Program (NHP) in 2019. It aimed to assess and compare healthy behaviors among children 
between 8 and 13 years of age. According to the study, overweight and obesity were reported among one third of both 8- and 13-year-olds. Among 8-year-olds, overweight was found in nearly one fifth of boys and girls. Obesity was recognized in $16.6 \%$ of boys and approximately $10 \%$ of girls. Among 13 -year-olds, obesity was less frequent and affected nearly $10 \%$ of boys and $6 \%$ of girls. Importantly, the study also collected basic anthropometric data. As evidenced by this data, one quarter of children 8 years of age and about one fifth of children 13 years of age had a waist circumference value at or above the $90^{\text {th }}$ percentile on relevant age and sex charts. These results confirm the fact young children exhibit symptoms of metabolic syndrome that should not be ignored [21].

A reliable source of data on adolescent health is systematically presented in the Health Behaviors in Schoolaged Children (HBSC) study, which is a WHO-approved Collaborative Cross-National Survey that is conducted in most European countries. In Poland, the latest report as part of the study was published in 2018. The results of that report showed that among more than 5,000 children 11-15 years of age, one-fifth (21.3\%) were found to have excess body mass. Obesity was recognized in nearly $5 \%$ of adolescents. Eating disorders were more characteristic of boys than girls, as revealed in our study as well. When comparing two groups of 13-year-old children, based on NHP and HBSC, there is a greater prevalence of overweight in the HBSC study than in the NHP study ( $23.4 \%$ vs. $29.1 \%$, respectively). According to the authors of these studies, the differences may be because the nutritional stage in the HBSC study was based on self-reported anthropometric data, so the numbers could be an underestimation [22]. Another large Polish study on the prevalence of overweight and obesity conducted by Harton et al. involving 14,044 adolescents 13-19 years of age evaluated nutritional status using IOTF criteria (children up to 18 years of age) and standardized WHO body mass index criteria (students 19 years of age). The data indicated that excess body mass was observed in nearly $20 \%$ respondents, of which $11.6 \%$ were overweight and $6.6 \%$ obese. These results are similar to those obtained in our study. Moreover, the Harton et al. study revealed decreasing prevalence of obesity with age as in other cited studies. The highest prevalence of obesity was noted among 13-year-old boys. Normal body mass was most common among 16-year-olds and this age group also had the fewest overweight students [23].

There are also many studies assessing children's nutritional status that do not cover the entire population. While they only involve select cities or regions, they still constitute a valuable source of data. In 2018, Glinkowska et al. published a study that showed a relatively low prevalence of obesity among children 10-19 years of age living in the Mazovian region. The study tool was an online survey and found that the prevalence of overweight did not exceed $8 \%$. Moreover, only $0.6 \%$ of participants were underweight [24]. In 2015, the authors of this study performed similar research to assess the nutritional stage and dietary habits of children living in a city located in the Silesian Voivodeship (Poland). The sample group of 508 children were between the ages of 6 and 13 years. Based on the BMI value (according to WHO standards), obesity was found in nearly one quarter of boys (23\%) and one fifth of girls (18\%). Nonetheless, overweight was also present in one fifth of boys and one quarter of girls. These numbers are much higher than those in our study. This can be due to the local-ness or region specificity of the study, which may give rise to similar lifestyles [25].

A year later, the same authors expanded the study scope, estimating nutritional status among rural area children living in the Silesia and Opole region (in the same age range). However, the results were similar as well. According to the data, obesity and overweight were present in nearly $40 \%$ of children. Obesity affected one quarter $(21.20 \%$ ) of boys and approximately $18 \%$ of girls, with $16 \%$ of boys and $20 \%$ of girls being overweight. Malnutrition was found in one fifth of children [26]. Kościej et al. also conducted an interesting study in the Silesia region. They used a survey distributed to parents of kindergarten children (3-6 years of age) to assess children's nutritional status. The survey included a question that allowed parents to estimate the nutritional status of their children on their own. The results showed that most parents claimed that their children had normal body mass. Nonetheless, upon performing calculations based on the anthropometric parameters provided by the parents (weight and height), the study authors determined that the percentage of children with a normal body mass was only $52 \%$. Overweight and obesity was present in $9 \%$ and $6 \%$ of boys and $3 \%$ and $5 \%$ of girls, respectively [27]. The results related to eating disorders are similar to our data, particularly in the case of boys. However, because of the different ages of the studied children, a comparative analysis would be unreliable. This study shows the importance of educating parents about the principles of body mass assessment from the earliest years of their children's lives. It is worth noting the vital role of pediatricians and general practitioners in the regular evaluation of a child's growth and making sure parents are aware of it. To this end, children's Medical Record Books also include special fields to be filled out during preventive care visits starting from the age of 2 .

Kwiecień et al. published a study estimating the prevalence of eating disorders in another region of Poland. The study was conducted in the Lublin Voivodeship and compared nutritional status among school pupils 7 (first grade) and 9 (third grade) years of age. The results showed that normal body mass was noted among 65\% of first-grade children, as well as $87 \%$ third graders. Overweight and obesity were recognized in $5 \%$ of first- 
grade children and 7\% of third-grade children. Importantly, nearly one third of first-graders were underweight, though this high value may have been due to the different underweight criteria used in the study. Based on the criteria, all BMI values under the 10th percentile (according to the BMI growth charts) were classified as underweight [28].

The last aspect of this discussion is about the poor response rate in this study, as only one fifth of parents sent back the questionnaires. The researchers believe there may be various factors to explain the low compliance. First, the study took place at schools with a lack of direct contact between parents and the researchers, which could have made return of the questionnaires more difficult. Moreover, the survey was voluntary. Additionally, in many cases, teachers handed out the surveys to children who were informed to give it to their parents but in practice, the researchers believe a large number of children may not have given it to them. This could be due to the young age of the children. Some parents also felt the survey was relatively difficult and long, which may have dissuaded some from completing and returning it. What is more, some parents expressed concern that the questions in the survey were "too private" or personal - for example, authors asked questions about family structure, level of parents education and number of parents who are financially earning. Due to the nature of some of these questions, it is possible that parents may not have completed the questionnaire because of inconvenience or shame. This can also be indirect evidence of poor awareness among some parents of the importance of nutrition and healthy behaviors. The response rate was very surprising particularly because some of the authors conducted a similar study in recent years for which the response rate was $62 \%$ [25].

This study also has some limitations. The main limitation is that anthropometric data were collected by interview and through survey, not through assessments. This can alter the results and underestimate eating disorders in a group. Because of the poor response rate and not having enough participants in the study, the results cannot be representative of the entire Polish children's population. However, our results are also comparable to other studies that had significantly more respondents. Additionally, our study focused on young children who are a unique group for which there are not many nutritional health studies. We hope to publish additional results from our study soon, which would include the last parts of the questionnaire including an overall evaluation of nutritional status. We believe this study has practical value because it serves as a reminder to general practitioners and pediatricians of the importance of basic anthropometric data measurements, assessments of nutritional state, as well as analysis of other factors which may determine nutritional status.

\section{Conclusions}

According to the results of this study, the prevalence of eating disorders among children is significant. Normal body mass was found in an average of three quarters of the studied population. Among girls, its percentage increases up to $90 \%$ among 8 -year-old girls. Obesity was the rarest eating disorder in the study group compared with overweight, which was the most common nutritional disorder. A similar percentage of underweight boys and girls was found. Overall, eating disorders were not more characteristic to any one sex.

\section{Disclosures and acknowledgements}

The authors declare no conflicts of interest with respect to the research, authorship, and/or publication of this article. The research was funded by the authors.

The authors would like to thank all the people who helped in the organization and implementation of the survey. We thank the heads of the schools for their support of this project.

\section{References:}

1. Corey KE, Kaplan LM. Obesity and liver disease: the epidemic of the twenty-first century. Clinics in Liver Disease. 2014; 18(1): 1-18. https://doi.org/10.1016/j.cld.2013.09.019

2. Robinson TN, Banda JA, Hale L, Lu AS, Fleming-Milici F, Calvert SL, et al. Screen media exposure and obesity in children and adolescents. Pediatrics. 2017; 140(Suppl 2): S97-S101. https://doi.org/10.1542/peds.2016$1758 \mathrm{~K}$

3. Czyż SH, Toriola AL, Starościak W, Lewandowski M, Paul Y, Oyeyemi AL. Physical fitness, physical activity, sedentary behavior, or diet-what are the correlates of obesity in Polish school children?. Int J Environ Res Public Health. 2017; 14(6): 664. https://doi.org/10.3390/ijerph14060664

4. Wittcopp C, Conroy R. Metabolic syndrome in children and adolescents. Pediatr Rev. 2016; 37(5): 193-202. https://doi.org/10.1542/pir.2014-0095 
5. Friend A, Craig L, Turner S. The prevalence of metabolic syndrome in children: a systematic review of the literature. Metab Syndr Relat Disord. 2013; 11(2): 71-80. https://doi.org/10.1089/met.2012.0122

6. Upadhyay R, Tripathi KD. How can we assess the nutritional status of an individual?. J Nutr Food Sci. 2017; 7: 6 .

7. Weir CB, Jan A. BMI classification percentile and cut off points. Treasure Island (FL): StatPearls Publishing; 2021.

8. de Onis M, Onyango AW, Borghi E, Siyam A, Nishida C, Siekmann J. Development of a WHO growth reference for school-aged children and adolescents. Bull World Health Organ. 2007; 85: 660-667. https://doi. org/10.2471/BLT.07.043497

9. Kuczmarski RJ, Ogden CL, Guo SS, Grummer-Strawn LM, Flegal KM, Mei Z, et al. 2000 CDC growth charts for the United States: methods and development. Vital Health Stat. 2002; 246: 1-190.

10. Cole TJ, Bellizzi MC, Flegal KM, Dietz WH. Establishing a standard definition for child overweight and obesity worldwide: international survey. BMJ. 2000; 320: 1240-1243. https://doi.org/10.1136/bmj.320.7244.1240

11. Kułaga Z, Różdżyńska-Świątkowska A, Grajda A, Gurzkowska B, Wojtyło M, Góźdź M, et al. [Percentile charts for growth and nutritional status assessment in Polish children and adolescents from birth to 18 year of age]. Standardy Medyczne. Pediatria. 2015; 12: 119-135 (in Polish).

12. Jarosz M., editor. [Nutrition norms for the Polish population]. Warszawa: Instytut Żywności i Żywienia; 2017 (in Polish).

13. Harrist AW, Swindle TM, Hubbs-Tait L, Topham GL, Shriver LH, Page MC. The social and emotional lives of overweight, obese, and severely obese children. Child Dev. 2016; 87(5): 1564-1580. https://doi.org/10.1111/ cdev.12548

14. Saylor CF, Williams KD, Nida SA, McKenna ME, Twomey KE, Macias MM. Ostracism in pediatric populations: review of theory and research. J Dev Behav Pediatr. 2013; 34(4): 279-287. https://doi.org/10.1097/ DBP.0b013e3182874127

15. World Health Organization. Overweight and obesity. WHO European Childhood Obesity Surveillance Initiative (COSI) Report on the fourth round of data collection, 2015-2017. Geneva: World Health Organization; 2021. p. 13-18.

16. Fryar CD, Carroll MD, Afful J. Prevalence of overweight, obesity, and severe obesity among children and adolescents aged 2-19 years: United States, 1963-1965 through 2017-2018. Hyattsville, Maryland: NCHS Health E-Stats.; 2020.

17. Malecka-Tendera E, Klimek K, Matusik P, Olszanecka- Glinianowicz M, Lehingue Y, Polish Childhood Obesity Study Group. Obesity and overweight prevalence in Polish 7- to 9-year-old children. Obes Res. 2005; 13(6): 964-968. https://doi.org/10.1038/oby.2005.112

18. Jodkowska M,Oblacińska A, Tabak I. Overweightand obesity amongadolescents in Poland:gender and regional differences. Public Health Nutr. 2010; 13(10A): 1688-1692. https://doi.org/10.1017/S1368980010002235

19. Brzeziński M, Jankowski M, Jankowska A, Niedzielska A, Kamińska B. Is there a rapid increase in prevalence of obesity in Polish children? An 18-year prospective observational study in Gdansk, Poland. Arch Med Sci. 2018; 14(1): 22-29. https://doi.org/10.5114/aoms.2018.72239

20. Kułaga Z, Grajda A, Gurzkowska B, Wojtyło MA, Góźdź M, Litwin MS. The prevalence of overweight and obesity among Polish school-aged children and adolescents. Przegl Epidemiol. 2016; 70(4): 641-651.

21. Dzielska A, Ostręga W. [Results of the anthropometric measurement, blood pressure and pulse]. In: Fijałkowska A, Oblacińska A, Korzycka M., editors. [Health and lifestyle among Polish pupils. Research report]. Warszawa: Instytut Matki i Dziecka; 2019. p. 21-29 (in Polish).

22. Oblacińska A. [Physical development and body mass self-assessment]. In: Mazur J, Małkowska-Szkutnik A., editors. [Schoolchildren's health in 2018 in context of the new model of HBSC research]. Warszawa: Instytut Matki i Dziecka; 2018. p. 70-81 (in Polish).

23. Harton A, Myszkowska-Ryciak J, Laskowski W, Gajewska D. Prevalence of overweight and obesity among adolescents in Poland. J Health Inequal. 2019; 5(2): 180-187. https://doi.org/10.5114/jhi.2019.91371

24. Glinkowska B, Glinkowski WM. Association of sports and physical activity with obesity among teenagers in Poland. Int J Occup Med Environ Health. 2018; 31(6): 771-782. https://doi.org/10.13075/ijomeh.1896.01170

25. Jonczyk P, Potempa M, Kajdaniuk D. [Level of nutrition and nutrition disorders as well as characteristics of dietary habits and physical activity among 6-13-year-old school children in the city of Piekary Śląskie in Poland]. Pediatr Med Rodz. 2015; 11(3): 302-314 (in Polish). https://doi.org/10.15557/PiMR.2015.0029

26. Jonczyk P, Potempa M, Kajdaniuk D. [Level of nutrition and nutrition disorders as well as characteristics of dietary habits and physical activity among 6-13-year-old children attending selected primary schools 
in Opole and Silesia Provinces in Poland]. Pediatr Med Rodz. 2016; 12(2): 177-193 (in Polish). https://doi. org/10.15557/PiMR.2016.0018

27. Kościej A, Skotnicka-Graca U, Bryś A. [Eating habits in children of preschool age from Katowice]. Piel Zdr Publ. 2018; 8(3): 163-170 (in Polish). https://doi.org/10.17219/pzp/81101

28. Kwiecień M, Winiarska-Mieczan A, Kwiatkowska K, Kamińska E, Rusinek-Przystupa E, Kiczorowska B, et al. [Evaluation of schoolchildren's dietary habits in terms of obesity prevalence]. Probl Hig Epidemiol. 2017; 98(3): 260-265 (in Polish). 